\title{
Black Disparities in Targeted Therapy Clinical Trials - A Call for Future Reset
}

\author{
SHOBI VENKATACHALAM MD, MOHAMMED AL-JUMAYLI MD \\ shobi.venkatachalam@mercyhealth.org \\ Mohammed.AlJumayli@moffitt.org
}

Simply Summarie: Targeted therapies target specific genes or molecules involved in cancer growth and survival more so than normal cells, consequently their side effects are fewer than conventional chemotherapy. Blacks are underrepresented in clinical trials involving cancer therapeutics including targeted therapies. This makes generalization of the data from these trials to the black population questionable because of possible differences in host and tumor biology depending on the race. This in turn might lead to disparities in treatment outcomes. Our study aims to highlight disparities in trial inclusion based on the data available from some of the pivotal and interesting targeted therapy trials including the ones that led to FDA approvals. We also review existing literature on how cancer treatment and treatment responses might differ based on the patient's race. In the end, we provide suggestions to enable better recruitment in clinical trials moving forward.

\begin{abstract}
Studies show marked disparities in the relative risk of cancer death between Black Americans and White Americans even after adjusting for the stage at diagnosis and age. This may be explained by disparities in different aspects of cancer care including providing equal screening opportunities, availability of proper treatment options and inclusivity in clinical trials. To our knowledge, our study is the first descriptive study on Black disparities in targeted therapy clinical trials. We collected data on Black inclusivity from pivotal clinical trials as well as trials of special interest involving targeted therapies in some of the commonly encountered cancers. Our results show that most targeted therapy trials included in our review were multinational including some participating countries with very few or no Blacks and therefore had very poor Black representation with an average of around 1-3\%. Also, some trials lacked transparent data on the racial demographics raising concerns on the generalizability of data when extrapolated to treat the Black population. We have reviewed existing literature on differences in cancer biology and host biology depending on the race and end with suggestions to improve Black inclusivity in clinical trials.
\end{abstract}

Keywords: Blacks; Disparities; Targeted therapy; Clinical trials

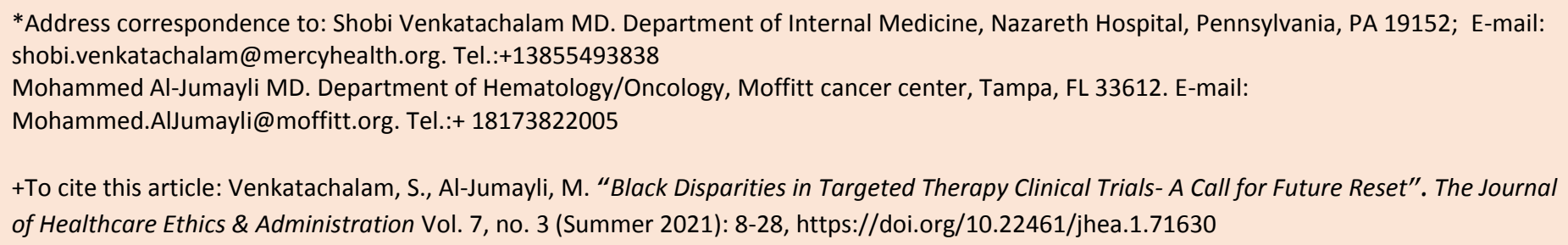

+To cite this article: Venkatachalam, S., Al-Jumayli, M. "Black Disparities in Targeted Therapy Clinical Trials- A Call for Future Reset". The Journal of Healthcare Ethics \& Administration Vol. 7, no. 3 (Summer 2021): 8-28, https://doi.org/10.22461/jhea.1.71630

This work is brought to you for free and open access by the Institute of Clinical Bioethics (ICB) at Saint Joseph's University, Philadelphia, PA, U.S.A. It has been accepted for inclusion in The Journal of Healthcare Ethics \& Administration by the editorial board and an authorized administrator of the JHEA. For more information, please contact support@jheaonline.org 


\section{THE JOURNAL OF HEALTHCARE ETHICS \& ADMINISTRATION}

Vol. 7 | No. 3 (Summer 2021)

\section{INTRODUCTION}

Blacks or African Americans (AAs) constitute about 13.4\% of the population in the United States (U.S.) (2019 U.S. census bureau)[1]. National data reveal improved Black-White racial disparity in cancer death rates since 1990. The cancer death rate disparities between Black males and White males have decreased from 47\% to 19\% and from 19\% to $13 \%$ between females from $1999-2017$. Despite improved disparities in death rates between AAs and Whites, there is still a significant gap in the relative risk for death between the two racial groups regardless of age and cancer stage at the diagnosis (33\% higher relative risk of death after a cancer diagnosis in Blacks compared to Whites)[2]. There are two hypotheses that contribute to these racial disparities in cancer outcomes. The first is racial differences in providing suitable treatment and the other is from differences in treatment responses[3]. Our study is a descriptive study on racial disparities in trial participation involving targeted therapies as non-chemotherapy options are becoming more and more the standard of care. To our knowledge, this is the first effort to study racial disparities in the participation of the most recent practice-changing trials.

Targeted therapies have revolutionized the treatment of many cancers like lung cancer, breast cancer, colon cancer, multiple myeloma and chronic myeloid leukemia (CML) by their ability to deliver the drug with high specificity and by being less toxic compared to conventional chemotherapy[4]. For example, advanced stage (stage III or IV) non-small cell lung cancer (NSCLC) patients previously had very limited treatment option as the tumor is relatively insensitive to chemotherapy. In an era of targeted therapy, patients with NSCLC harboring epidermal growth factor receptor (EGFR) mutations or anaplastic lymphoma kinase (ALK) gene rearrangements have significantly improved outcomes as compared to chemotherapy as these can be targeted with EGFRtyrosine kinase inhibitors or ALK-tyrosine kinase inhibitors (ALK-TKIs) respectively[5]. The dawn of targeted therapy along with Next Generation Gene sequencing has shifted medicine from "one size fits all" to more personalized treatment paradigms that could potentially curtail health care costs in the future. Considering that targeted agents are important milestones in the future of cancer therapy, the current concern is on the need for improved efforts on fairness in the inclusion of minorities like AAs in trials involving targeted therapy.

\section{MATERIALS AND METHODS}

We used the latest clinical guidelines for the widely used targeted therapies in different types of cancers like breast cancer, prostate cancer, colon cancer, lung cancer, liver cancer, renal cell cancer, melanomas and leukemias. We included small molecule inhibitors, monoclonal antibodies, and antibody-drug conjugates. We searched PubMed, Google Scholar and Medscape using mesh terms incorporating the selected therapy and the selected cancer type, example "(Sorafenib [MeSH Terms]) AND (renal cell cancer [MeSH Terms]". We identified pivotal clinical trials that lead to drug approval or clinical trials of special interest for each type of cancer mentioned above. We excluded trials that included smaller numbers of patients and trials other than in English language. If there was no data available on Black inclusivity in the manuscript or under the results column of a trial (at clinical trials.gov), it was recorded as "No data available". Twelve out of the 84 studies included were non-randomized phase 1 or phase 2 trials. Most studies were multinational with very few studies (7 out of 84 ) based mainly in the USA. 


\section{RESULTS}

\begin{tabular}{|c|c|c|c|c|c|c|c|c|}
\hline $\begin{array}{l}\text { Investigational } \\
\text { agent(s) }\end{array}$ & Study name & Ref. & $\begin{array}{l}\text { Study } \\
\text { year }\end{array}$ & $\begin{array}{c}\text { Total } \\
\text { population of } \\
\text { study }\end{array}$ & $\begin{array}{l}\text { Percentage of } \\
\text { Blacks }\end{array}$ & $\begin{array}{c}\text { Type of the } \\
\text { study }\end{array}$ & $\begin{array}{l}\text { Single or } \\
\text { combined }\end{array}$ & Indication \\
\hline $\begin{array}{c}\text { Trastuzumab vs } \\
\text { observation }\end{array}$ & HERA & [6] & 2001 & 3387 & Black-0.6\% & Phase 3 & Single & $\begin{array}{c}\text { HER2-positive early stage } \\
\text { breast cancer }\end{array}$ \\
\hline $\begin{array}{c}\text { Doxorubicin, } \\
\text { Cyclophosphamide } \\
\text { and Paclitaxel with } \\
\text { or without } \\
\text { Trastuzumab }\end{array}$ & NSABP B-31 & [7] & 2000 & 2102 & $\begin{array}{l}\text { No data } \\
\text { available }\end{array}$ & Phase 3 & Combined & $\begin{array}{l}\text { HER2-positive, node } \\
\text { positive breast cancer }\end{array}$ \\
\hline $\begin{array}{c}\text { Doxorubicin, } \\
\text { Cyclophosphamide } \\
\text { and Paclitaxel with } \\
\text { or without } \\
\text { Trastuzumab } \\
\end{array}$ & NCCTG N9831 & [7] & 2000 & 1944 & $\begin{array}{l}\text { No data } \\
\text { available }\end{array}$ & Phase 3 & Combined & $\begin{array}{l}\text { HER2-positive, node } \\
\text { positive or high-risk node } \\
\text { negative breast cancer }\end{array}$ \\
\hline $\begin{array}{c}\text { Trastuzumab } \\
\text { Emtansine vs } \\
\text { treatment of } \\
\text { physician's choice }\end{array}$ & TH3RESA & [10] & 2011 & 602 & $\begin{array}{l}\text { No data } \\
\text { available }\end{array}$ & Phase 3 & Single & $\begin{array}{l}\text { HER2-positive advanced } \\
\text { breast cancer }\end{array}$ \\
\hline $\begin{array}{c}\text { Lapatinib vs } \\
\text { Trastuzumab vs } \\
\text { Lapatinib plus } \\
\text { Trastuzumab } \\
\end{array}$ & Neo-ALTTOO & [11] & 2008 & 455 & Black-1.7\% & Phase 3 & & $\begin{array}{l}\text { HER2-positive early breast } \\
\text { cancer }\end{array}$ \\
\hline $\begin{array}{c}\text { Doxorubicin and } \\
\text { Cyclophosphamide } \\
\text { followed by } \\
\text { Paclitaxel plus } \\
\text { Trastuzumab or } \\
\text { Lapatinib or both }\end{array}$ & $\begin{array}{l}\text { NSABP protocol } \\
\text { B-41 }\end{array}$ & [12] & 2007 & 529 & Black-8\% & Phase 3 & Combined & $\begin{array}{l}\text { HER2-positive operable } \\
\text { breast cancer }\end{array}$ \\
\hline $\begin{array}{c}\text { Fluorouracil, } \\
\text { Epirubicin, and } \\
\text { Cyclophosphamide } \\
\text { followed by } \\
\text { Paclitaxel plus } \\
\text { Trastuzumab or } \\
\text { Lapatinib or both } \\
\end{array}$ & CHER-LOB & {$[14]$} & 2006 & 121 & $\begin{array}{l}\text { No data } \\
\text { available }\end{array}$ & Phase 2 & Combined & $\begin{array}{l}\text { HER2-positive operable } \\
\text { breast cancer }\end{array}$ \\
\hline $\begin{array}{l}\text { Trastuzumab and } \\
\text { Pertuzumab } \\
\text { without and with } \\
\text { metronomic } \\
\text { Cyclophosphamide }\end{array}$ & $\begin{array}{l}\text { EORTC 7511- } \\
10114\end{array}$ & [15] & 2013 & 80 & $\begin{array}{l}\text { No data } \\
\text { available }\end{array}$ & Phase 2 & Combined & $\begin{array}{l}\text { Her } 2 \text { positive advanced } \\
\text { breast cancer }\end{array}$ \\
\hline $\begin{array}{l}\text { Trastuzumab and } \\
\text { Docetaxel plus } \\
\text { Placebo vs } \\
\end{array}$ & CLEOPATRA & [16] & 2008 & 808 & Black- $3.7 \%$ & Phase 3 & Combined & $\begin{array}{l}\text { HER2-positive advanced } \\
\text { breast cancer }\end{array}$ \\
\hline
\end{tabular}


THE JOURNAL OF HEALTHCARE ETHICS \& ADMINISTRATION

Vol. 7 | No. 3 (Summer 2021)

\begin{tabular}{|c|c|c|c|c|c|c|c|c|}
\hline $\begin{array}{c}\text { Trastuzumab and } \\
\text { Docetaxel plus } \\
\text { Pertuzumab } \\
\end{array}$ & & & & & & & & \\
\hline $\begin{array}{l}\text { Exemestane with } \\
\text { and without } \\
\text { Everolimus }\end{array}$ & BOLERO-2 & [17] & 2009 & 724 & Black-2.3\% & Phase 3 & Combined & $\begin{array}{l}\text { ER positive, HER2 negative } \\
\text { advanced breast cancer }\end{array}$ \\
\hline $\begin{array}{c}\text { Olaparib vs } \\
\text { standard single- } \\
\text { agent } \\
\text { chemotherapy } \\
\text { (Capecitabine, } \\
\text { Eribulin or } \\
\text { Vinorelbine) }\end{array}$ & OlympiAD & [18] & 2014 & 302 & Black-1.7\% & Phase 3 & Single & $\begin{array}{c}\text { Germline BRCA mutation } \\
\text { positive and HER2 negative } \\
\text { metastatic breast cancer }\end{array}$ \\
\hline Erlotinib vs Placebo & SATURN & [19] & 2006 & 889 & $\begin{array}{l}\text { No data } \\
\text { available }\end{array}$ & Phase 3 & Single & Advanced NSCLC \\
\hline $\begin{array}{l}\text { Erlotinib vs } \\
\text { standard Docetaxel } \\
\text { or Pemetrexed } \\
\text { regimens }\end{array}$ & TITAN & [20] & 2006 & 424 & $\begin{array}{l}\text { No data } \\
\text { available }\end{array}$ & Phase 3 & Single & Advanced NSCLC \\
\hline $\begin{array}{c}\text { Erlotinib vs } \\
\text { standard } \\
\text { chemotherapy (i.e } \\
\text { Cisplatin plus } \\
\text { Docetaxel or } \\
\text { Gemcitabine or } \\
\text { Carboplatin plus } \\
\text { Docetaxel or } \\
\text { Gemcitabine) } \\
\end{array}$ & EURTAC & [21] & 2007 & 173 & $\begin{array}{l}\text { No data } \\
\text { available }\end{array}$ & Phase 3 & Single & $\begin{array}{l}\text { EGFR mutation positive } \\
\text { NSCLC }\end{array}$ \\
\hline Erlotinib vs Placebo & & {$[22]$} & 2001 & 731 & Black-4\% & Phase 3 & Single & $\begin{array}{c}\text { NSCLC after first line or } \\
\text { second line chemotherapy }\end{array}$ \\
\hline Alectinib & NP28761 & [23] & 2013 & 87 & $\begin{array}{l}\text { No data } \\
\text { available }\end{array}$ & Phase 2 & Single & $\begin{array}{c}\text { Stage IIIB-IV, ALK-positive } \\
\text { NSCLC }\end{array}$ \\
\hline Alectinib & NP28673 & [24] & 2013 & 138 & $\begin{array}{l}\text { No data } \\
\text { available }\end{array}$ & Phase 2 & Single & $\begin{array}{c}\text { ALK-positive NSCLC } \\
\text { including those with CNS } \\
\text { metastasis }\end{array}$ \\
\hline $\begin{array}{l}\text { Alectinib vs } \\
\text { Crizotinib }\end{array}$ & ALEX & {$[25]$} & 2014 & 303 & Black-1.3\% & Phase 3 & Single & ALK-positive NSCLC \\
\hline $\begin{array}{l}\text { Ceritinib vs } \\
\text { Pemetrexed or } \\
\text { Docetaxel }\end{array}$ & ASCEND-1 & {$[26]$} & 2011 & 304 & Black-1.3\% & Phase 3 & Single & $\begin{array}{l}\text { ALK-rearranged advanced } \\
\text { NSCLC }\end{array}$ \\
\hline Crizotinib & PROFILE1001 & [27] & 2006 & 149 & $\begin{array}{l}\text { No data } \\
\text { available }\end{array}$ & Phase 1 & Single & $\begin{array}{l}\text { Locally advanced or } \\
\text { metastatic ROS1 } \\
\text { rearrangement positive } \\
\text { NSCLC }\end{array}$ \\
\hline $\begin{array}{l}\text { Crizotinib vs } \\
\text { Pemetrexed or } \\
\text { Docetaxel }\end{array}$ & & [28] & 2009 & 347 & $\begin{array}{l}\text { No data } \\
\text { available }\end{array}$ & Phase 3 & Single & $\begin{array}{l}\text { Locally advanced or } \\
\text { metastatic ALK positive } \\
\text { NSCLC }\end{array}$ \\
\hline $\begin{array}{c}\text { Afatinib vs } \\
\text { Cisplatin- } \\
\text { Pemetrexed }\end{array}$ & LUX-Lung 3 & $\begin{array}{l}{[29,} \\
30]\end{array}$ & 2009 & 345 & $\begin{array}{l}\text { No data } \\
\text { available }\end{array}$ & Phase 3 & Single & $\begin{array}{l}\text { EGFR mutation-positive } \\
\text { lung adenocarcinoma }\end{array}$ \\
\hline $\begin{array}{l}\text { Afatinib vs } \\
\text { Cisplatin- } \\
\text { Gemcitabine }\end{array}$ & LUX-Lung 6 & $\begin{array}{l}{[29,} \\
31]\end{array}$ & 2010 & 364 & No Blacks & Phase 3 & Single & $\begin{array}{l}\text { EGFR mutation-positive } \\
\text { lung adenocarcinoma }\end{array}$ \\
\hline $\begin{array}{l}\text { Afatinib vs } \\
\text { Gefitinib }\end{array}$ & LUX-Lung-7 & [32] & 2011 & 319 & Black-0.3\% & Phase 2 & Single & $\begin{array}{c}\text { EGFR mutation positive lung } \\
\text { adenocarcinoma }\end{array}$ \\
\hline Gefitinib vs & IPASS & [33] & 2006 & 1217 & No data & Phase 3 & Single & Stage IIIB or IV non-small- \\
\hline
\end{tabular}


THE JOURNAL OF HEALTHCARE ETHICS \& ADMINISTRATION

Vol. 7 | No. 3 (Summer 2021)

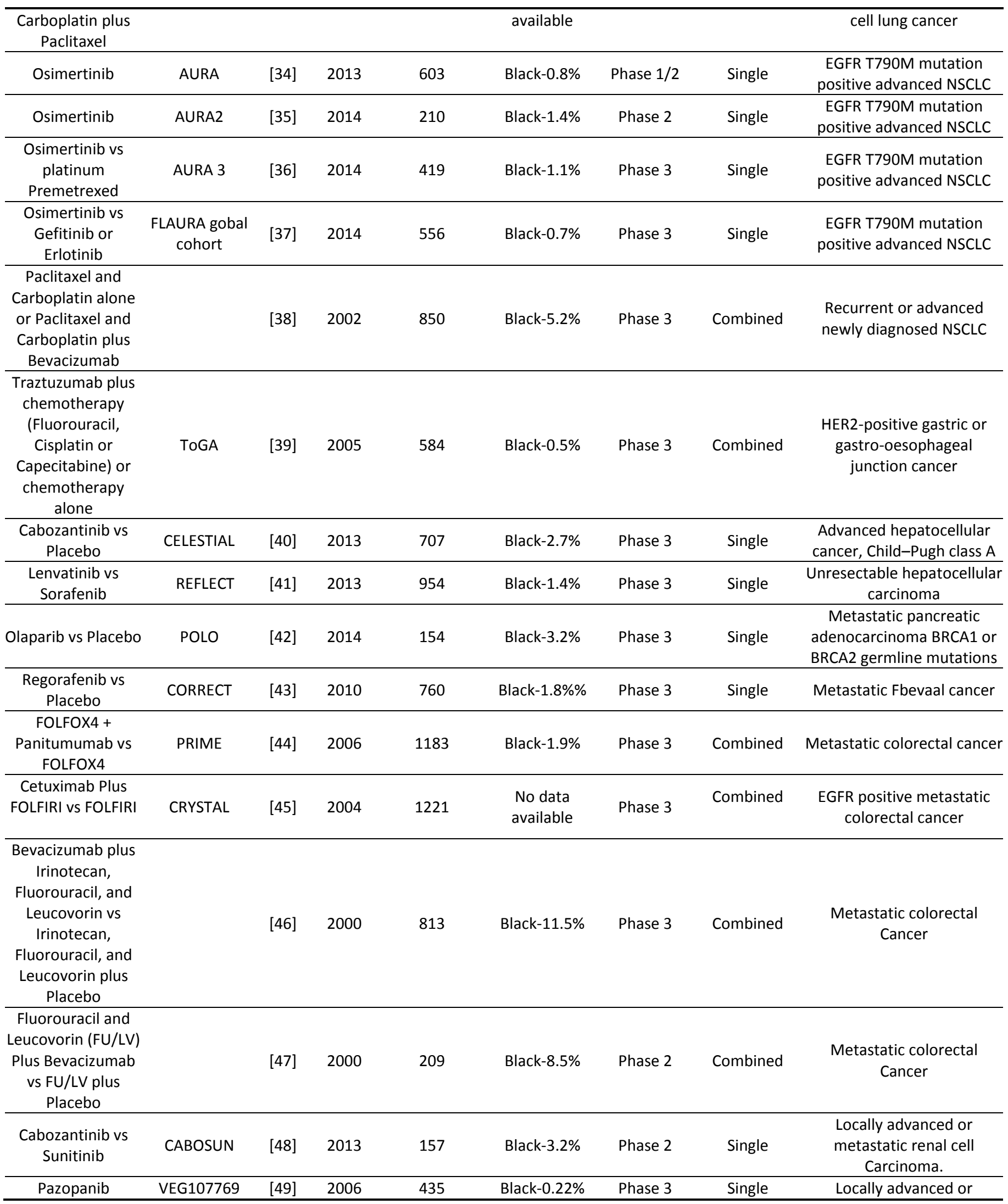


THE JOURNAL OF HEALTHCARE ETHICS \& ADMINISTRATION

Vol. 7 | No. 3 (Summer 2021)

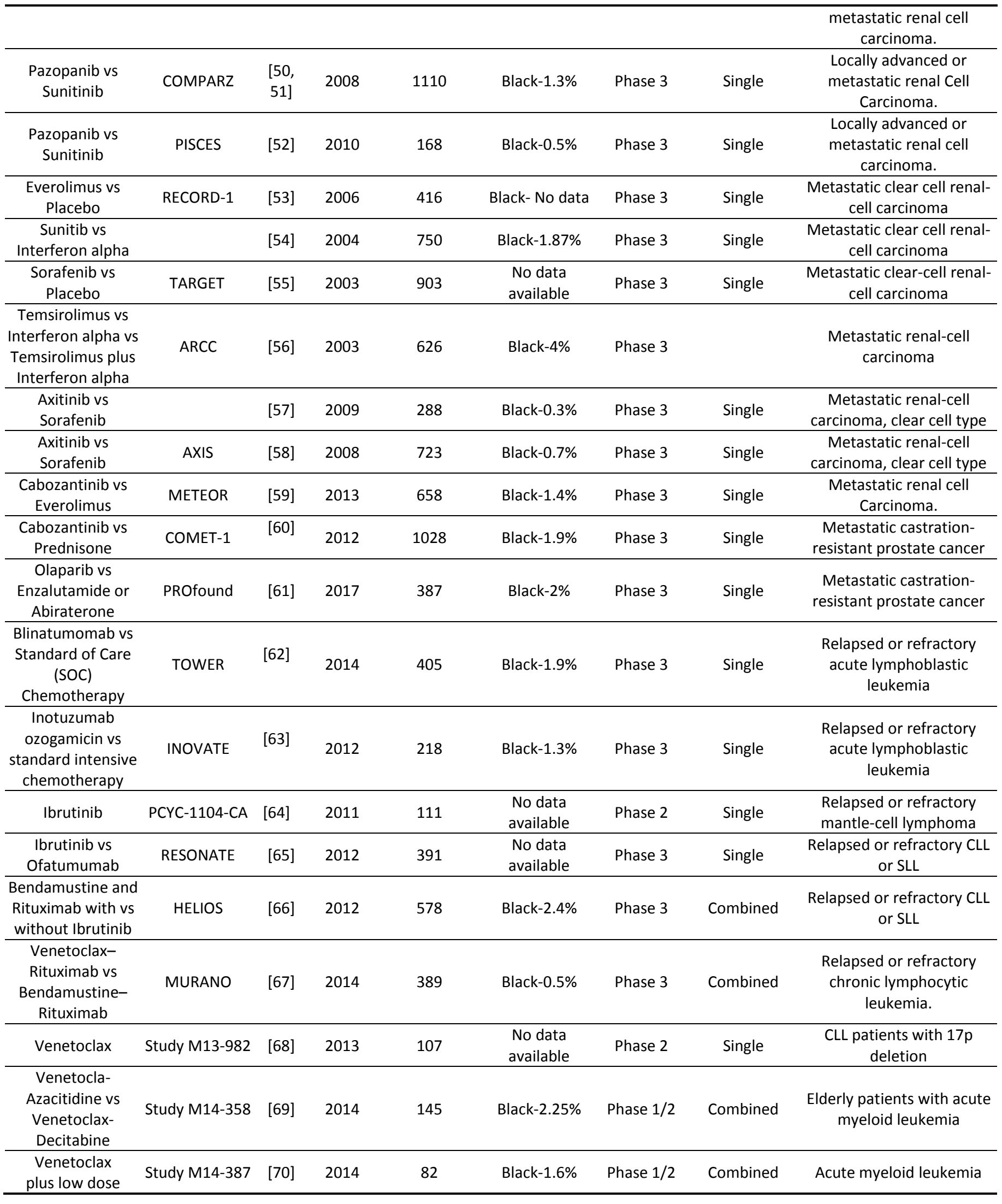


THE JOURNAL OF HEALTHCARE ETHICS \& ADMINISTRATION

Vol. 7 | No. 3 (Summer 2021)

\begin{tabular}{|c|c|c|c|c|c|c|c|c|}
\hline Cytarabine & & & & & & & & \\
\hline $\begin{array}{l}\text { Daunorubicin plus } \\
\text { Cytarabine with } \\
\text { and without } \\
\text { Gemtuzumab } \\
\text { Ozogamicin }\end{array}$ & ALFA-0701 & [71] & 2007 & 280 & N/A & Phase3 & Combined & $\begin{array}{l}\text { Untreated acute myeloid } \\
\text { leukemia }\end{array}$ \\
\hline Ivosidenib & AG120-C-001 & $\begin{array}{l}{[72,} \\
73]\end{array}$ & 2014 & 201 & Black-5.9\% & Phase 1 & Single & $\begin{array}{l}\text { Acute myeloid leukemia } \\
\text { with an IDH1 mutation }\end{array}$ \\
\hline Enasidenib & AG221-C-001 & $\begin{array}{l}{[74,} \\
75]\end{array}$ & 2013 & 343 & Black-5.5\% & Phase1/2 & Single & $\begin{array}{c}\text { Advanced hematologic } \\
\text { malignancies with an IDH2 } \\
\text { mutation }\end{array}$ \\
\hline $\begin{array}{l}\text { Daunorubicin, } \\
\text { Cytarabine with } \\
\text { and without } \\
\text { Midostaurin }\end{array}$ & & [76] & 2008 & 717 & Black-2.4\% & Phase 3 & Combined & $\begin{array}{c}\text { Newly diagnosed acute } \\
\text { myeloid leukemia with FLT3 } \\
\text { mutation }\end{array}$ \\
\hline $\begin{array}{l}\text { Imatinib vs } \\
\text { Interferon- } \alpha \text { with } \\
\text { Cytarabine }\end{array}$ & IRIS & [78] & 2000 & 1106 & Black-5\% & Phase 3 & Single & $\begin{array}{c}\text { Newly diagnosed } \\
\text { Philadelphia chromosome } \\
\text { positive chronic phase- } \\
\text { chronic myelogenous } \\
\text { leukemia }\end{array}$ \\
\hline $\begin{array}{l}\text { Dasatinib vs } \\
\text { Imatinib }\end{array}$ & DASISION & [79] & 2007 & 519 & Black-0.5\% & Phase 3 & Single & $\begin{array}{c}\text { Newly diagnosed } \\
\text { Philadelphia chromosome } \\
\text { positive chronic phase- } \\
\text { chronic myelogenous } \\
\text { leukemia }\end{array}$ \\
\hline $\begin{array}{l}\text { Nilotinib vs } \\
\text { Imatinib }\end{array}$ & ENESTnd & [82] & 2007 & 846 & Black-3.5\% & Phase 3 & Single & $\begin{array}{c}\text { Newly diagnosed } \\
\text { Philadelphia chromosome } \\
\text { positive chronic phase- } \\
\text { chronic myelogenous } \\
\text { leukemia }\end{array}$ \\
\hline $\begin{array}{l}\text { Bosutinib vs } \\
\text { Imatinib }\end{array}$ & BEFORE & [83] & 2014 & 487 & Black-4.1\% & Phase 3 & Single & $\begin{array}{c}\text { Newly diagnosed } \\
\text { Philadelphia chromosome } \\
\text { positive chronic phase- } \\
\text { chronic myelogenous } \\
\text { leukemia }\end{array}$ \\
\hline $\begin{array}{c}\text { Bortezomib, } \\
\text { Melphalan, and } \\
\text { Prednisone with vs } \\
\text { without } \\
\text { Daratumumab }\end{array}$ & ALCYONE & [84] & 2014 & 706 & Black-0.8\% & Phase 3 & Combined & $\begin{array}{l}\text { Newly diagnosed Multiple } \\
\text { Myeloma ineligible for } \\
\text { stem-cell transplantation }\end{array}$ \\
\hline $\begin{array}{l}\text { Lenalidomide and } \\
\text { Dexamethasone } \\
\text { with vs without } \\
\text { Daratumumab }\end{array}$ & POLLUX & [85] & 2014 & 569 & Black-2.8\% & Phase 3 & Combined & $\begin{array}{l}\text { Relapsed or refractory } \\
\text { Multiple Myeloma }\end{array}$ \\
\hline
\end{tabular}


THE JOURNAL OF HEALTHCARE ETHICS \& ADMINISTRATION

Vol. 7 | No. 3 (Summer 2021)

\begin{tabular}{|c|c|c|c|c|c|c|c|c|}
\hline $\begin{array}{l}\text { Bortezomib and } \\
\text { Dexamethasone } \\
\text { with vs without } \\
\text { Daratumumab }\end{array}$ & CASTOR & [86] & 2014 & 498 & Black-3.6\% & Phase 3 & Combined & $\begin{array}{l}\text { Relapsed or refractory } \\
\text { Multiple Myeloma }\end{array}$ \\
\hline $\begin{array}{l}\text { Dabrafenib Plus } \\
\text { Trametinib vs } \\
\text { Vemurafenib }\end{array}$ & COMBI-v & [87] & 2012 & 704 & Black-0.1\% & Phase 3 & Combined & $\begin{array}{c}\text { Unresectable or metastatic } \\
\text { BRAF V600E/K mutation- } \\
\text { positive cutaneous } \\
\text { melanoma }\end{array}$ \\
\hline $\begin{array}{l}\text { Dabrafenib vs } \\
\text { Dabrafenib plus } \\
\text { Trametinib }\end{array}$ & COMBI-d & [88] & 2012 & 422 & Black-0.2\% & Phase 3 & & $\begin{array}{l}\text { Unresectable or metastatic } \\
\text { BRAF V600E/K mutation- } \\
\text { positive cutaneous } \\
\text { melanoma }\end{array}$ \\
\hline $\begin{array}{l}\text { Dabrafenib vs } \\
\text { Dacarbazine }\end{array}$ & BREAK-3 & [89] & 2010 & 251 & No blacks & Phase 3 & Single & $\begin{array}{c}\text { BRAF mutation positive } \\
\text { advanced or metastatic } \\
\text { melanoma }\end{array}$ \\
\hline $\begin{array}{l}\text { Vemurafenib vs } \\
\text { Dacarbazine }\end{array}$ & BRIM-3 & [90] & 2010 & 675 & No blacks & Phase 3 & Single & $\begin{array}{l}\text { BRAF mutation positive } \\
\text { advanced or metastatic } \\
\text { melanoma }\end{array}$ \\
\hline
\end{tabular}

Table 1. Targeted therapy clinical trials and Black inclusion rate

A. Breast Cancer

\section{Targeted therapy trials-Breast cancer}

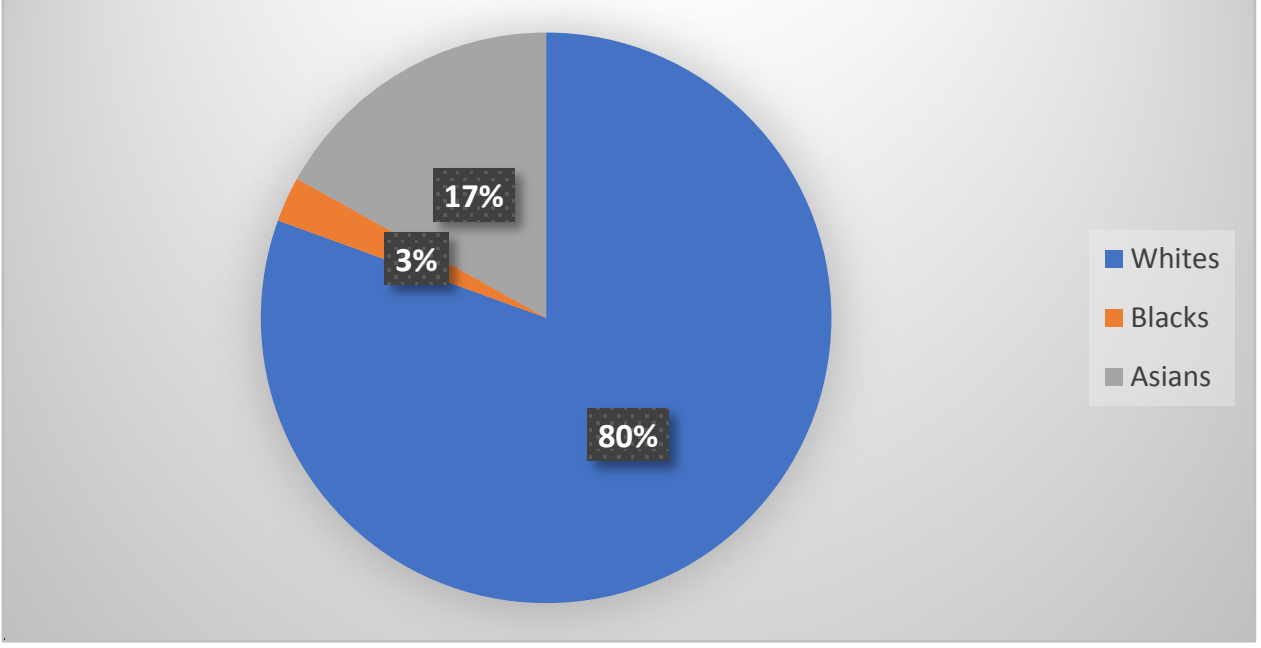

Figure 1. Black inclusion in breast cancer trials

On an average, breast cancer trials included in our review included about 3\% blacks (Figure 1). Even the HERA trial that studied Trastuzumab in a significantly larger number of women (3387 patients) with HER-2 positive primary breast cancer after locoregional therapy and neoadjuvant or adjuvant chemotherapy included only $0.6 \%$ Black women compared to $83.15 \%$ White women. The trials involving HER-2 targeted therapy (Trastuzumab, Trastuzumab Emtansine, Pertuzumab and Lapatinib) in our review had about $0.5 \%$ to $8 \%$ of Black patients (Table 1). Also, the OlympiAD trial which studied Olaparib compared to standard chemotherapy in germline BRCA mutated metastatic breast cancer patients had only $1.7 \%$ Black patients included[18]. 
The incidence of breast cancer is less in AA women compared to white women (126.7 per 100,000 females compared to 130.8 cases per 100,000 females from 2012-2016) but they are more likely to be diagnosed with advanced disease (43\% vs $34 \%$ in white women) and have higher death rates compared to white women (28.7\% vs $20.3 \%$, 2013-2017)[91, 92]. Along with socioeconomic components like poverty and lack of insurance, beliefs among Black women that they are at lower risk for breast cancer regardless of their family history, lower preferences for surgical treatment and lower referrals for mammography by their primary physician contribute to racial disparities in breast cancer[93-95]. In addition, black women have low vitamin D levels, as dense melanin in their skin limits vitamin $D$ absorption from the sun. And, low vitamin $D$ levels have been associated with the poorly prognostic triple negative breast tumors[96]. Also, Black women have more coexisting comorbidities like hypertension, obesity, diabetes mellitus, cardiovascular and pulmonary disease limiting treatment options[97].

\section{B. Colorectal Cancer}

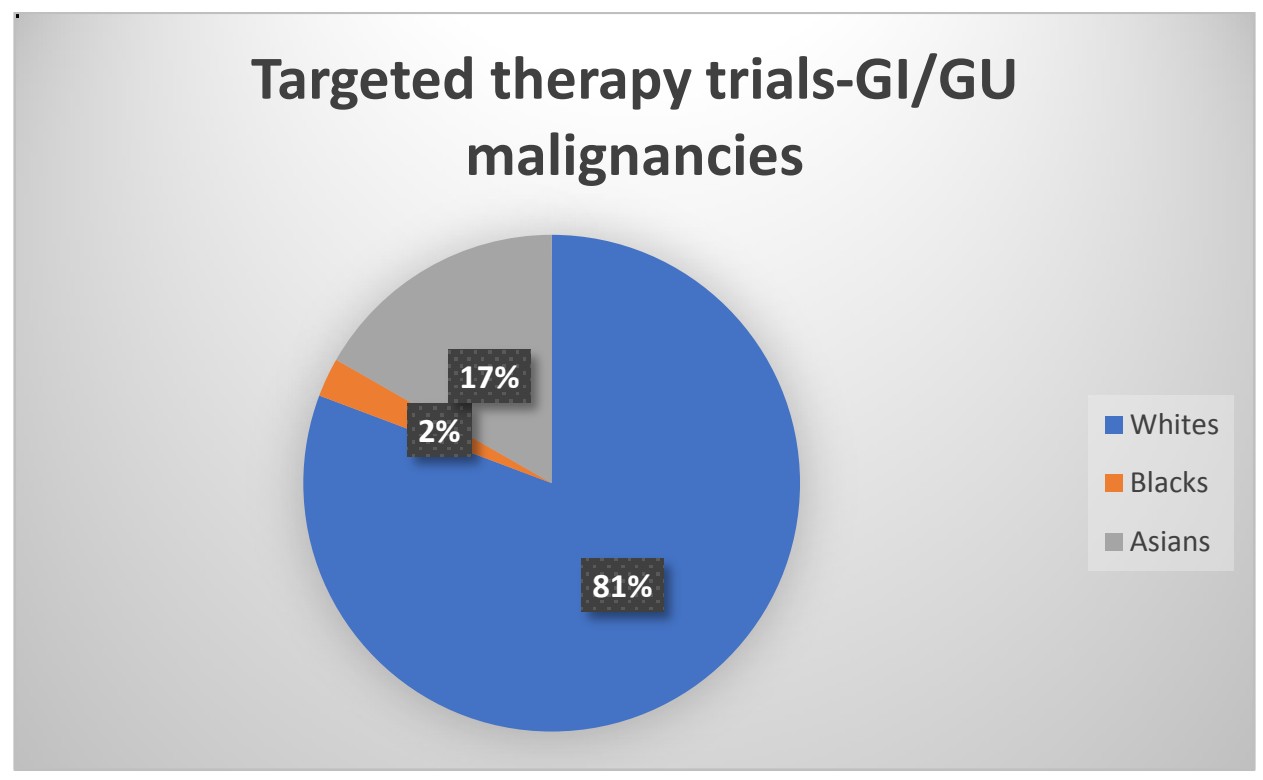

Figure 2. Black inclusion in Gastrointestinal (GI)/Genitourinary (GU) cancer trials

Overall Gastrointestinal cancer trials including hepatocellular cancers and genitourinary cancer trials including prostate cancer had about $2 \%$ Black inclusivity (Figure 2). For Colorectal cancer (CRC), our data shows that the percentage of Black inclusivity was $<2 \%$ in the CORRECT trial (Regorafenib) as well as the PRIME (Panitumumab) trial and no data was available on the CRYSTAL trial (Cetuximab). Surprisingly trials involving Bevacizumab had better representation of blacks at $8-11 \%$ compared to other targeted therapy colon cancer trials included in our review (Table 1).

CRC is another cancer where the incidence and mortality rates per 100,000 are considerably higher in Blacks compared to Whites [45.7 versus (vs) 38.6 and 19 vs 13.8 respectively][98]. Differences like lower likelihood of participation in screening among Blacks with a positive family history of CRC, inaccurate knowledge of family history and inadequate follow-up of abnormal screening on colonoscopy leads to diagnosis at a more advanced stage[99]. AAs are also more likely to be diagnosed at a younger age and with more proximal tumors. In one study $10.6 \%$ of CRC in AAs were diagnosed before 45 years compared to $5.5 \%$ in Whites[100]. Biology of CRC is also different with more proximal tumors, more frequent KRAS mutations and less frequent microsatellite instability among Blacks with colorectal cancers[101, 102]. 


\section{THE JOURNAL OF HEALTHCARE ETHICS \& ADMINISTRATION}

Vol. 7 | No. 3 (Summer 2021)

\section{c. Hepatocellular Cancer}

The CELESTIAL trial, a pivotal phase III trial that lead to FDA approval of Cabozantinib in advanced previously treated hepatocellular carcinoma patients included only $2.7 \%$ Blacks[7]. The REFLECT (Lenvatinib), SHARP and AP (Sorafenib) trials in advanced unresectable hepatocellular cancer patients included only about 1.5\% Blacks on an average[103] (Table 1).

According to cancer statistics 2020, AAs with primary hepatocellular carcinoma have higher incidences and mortality rates compared to Whites (17.9 vs 10.5 per 100,000 and 8.6 vs 5.8 per 100,000 respectively). These rates include hepatocellular carcinoma and cancers of intrahepatic bile ducts combined[98]. The lower survival rates are because of more advanced tumor stages at diagnosis and lower rates of curative treatment including surgery, and liver transplantation[104-106]. With targeted therapies like sorafenib, Lenvatinib, Cabozantinib, regorafenib and Bevacizumab playing a major role in the treatment paradigm of unresectable hepatocellular cancer, Blacks need better representation in these trials.

\section{Renal Cancer}

Based on our review data the METEOR trial that studied Cabozantinib (a small molecule inhibitor of c-Met and VEGFR2 tyrosine kinases) in advanced renal cell carcinoma patients previously treated with one or more VEGFR tyrosine-kinase inhibitors included only $1.4 \%$ of Black patients, whereas, around $80 \%$ were Whites. Similarly, in the AXIS trial where Axitinib was compared with sorafenib in clear cell renal cell carcinoma (ccRCC) patients only about $0.7 \%$ were Blacks. Blacks were underrepresented in the COMPARZ and PISCES trials comparing pazopanib with sunitinib in treatment naive patients with ccRCC with $1.3 \%$ and $0.5 \%$ of Blacks in each trial respectively. The TARGET (sorafenib) and RECORD-1 (Everolimus) trials were either minimally inclusive or had no data on Black inclusion despite being phase 3 FDA approval trials (Table 1).

The rates of kidney and renal pelvic cancers in Black men is 25.4 per 100,000 compared to 22.5 per 100,000 in White men. Similarly, the rates are higher among Black women at 13.1 per 100,000 compared to 11.4 per 100,000 among White women[98]. Seventy percent of these cancers are clear cell cancers. Other less common types include papillary and chromophobe tumors[107]. While the clear cell subtype is more common among AAs compared to White Americans, AAs have a greater risk of renal cell cancer (RCC) in general than White Americans but have lower nephrectomy rates[108]. In addition, a study examining tumor data sets from 419 White and 19 AA patients with clear cell renal cell carcinoma found that AA patients have less frequent VHL mutations and correspondingly lower hypoxia-inducible factor (HIF) and VEGF pathway activation suggesting less responsiveness to VEGF targeted therapy[109]. Thus, the tumor biology is different among different racial groups supporting the need for better Black inclusivity in clinical trials involving RCC.

\section{E. Prostate Cancer}

The COMET-1 phase 3 trial that studied Cabozantinib in comparison to Prednisone in 1028 patients with metastatic castrationresistant prostate cancer and the PROfound trial (a FDA approval trial) which studied the BRCA inhibitor Olaparib in patients with metastatic castration resistant prostate cancer (mCRPC) had only about 2\% Black's enrolled in each (Table 1).

These low numbers are despite prostate cancer being 1.75 times more common in Black men (179.2 vs 101.7 per 100,000) compared to White men[98]. Prostate cancer presents at a younger age and at more advanced stages in Black men[110]. A large study of 1801 AA men who met NCCN criteria for very low risk cancer and thereby would be candidates for active surveillance but elected to undergo radical prostatectomy showed larger tumor burden, disease upgrading, positive surgical margins and adverse pathology at prostatectomy. This in turn on multivariable analysis resulted in AA race alone being an independent predictor of adverse oncologic outcomes in the same study[111]. AA men also present with higher prostate specific antigen (PSA) levels, probably because of higher tumor volumes overall in these men[112]. Conversely, anterior tumors of the prostate gland which are poorly PSA producing, more aggressive and less likely to be picked up on a digital rectal exam are more prevalent in AA explaining at least partially why AAs progress on active surveillance compared to European American men (EAM) $[113,114]$. All these high-risk features translate to significantly higher mortality rates (38.7 vs 18 per 100,000) in AAs with prostate cancer compared to White men[98]. Genetically AAs have a higher frequency of BMP2 (20p12) and CXCR4 (2q22) gene upregulation, both of which are associated with metastasis[115]. A study of BRCA1 and BRCA2 genes via sequencing of archived DNA specimens from prostate 
cancer patients undergoing radical prostatectomy $(n=1139)$ showed more frequent pathogenic and variants of uncertain significance (VUS) BRCA1/2 gene mutations in AA men compared to White men (7.3\% vs $2.2 \%)$. This translated to a trend towards increased metastasis in these patients[116]. Considering these facts, the American cancer society recommends initiating prostate cancer screening discussions at 45 years of age in AA men compared to 50 years of age in men with average risk[117].

\section{F. Lung Cancer}

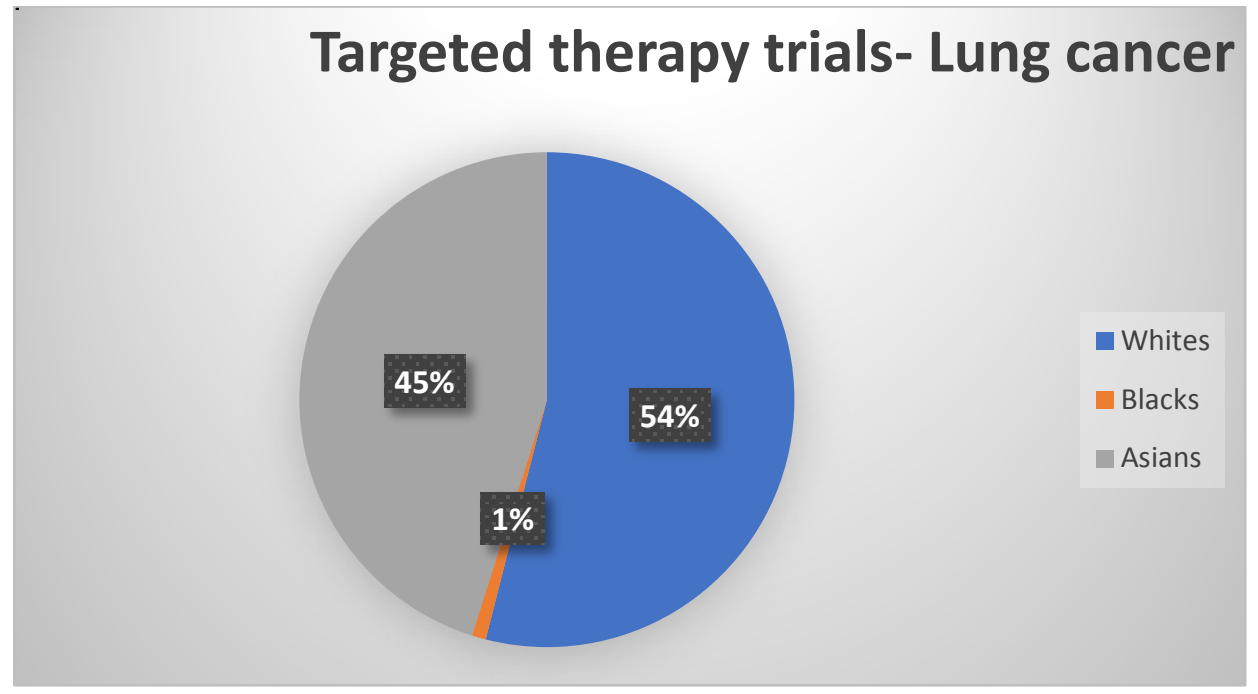

Figure 3. Black inclusion in lung cancer trials

There was a paucity on Black inclusivity data in the EURTAC trial which is phase 3 trials that lead to FDA approval of erlotinib in EGFR mutation positive NSCLC with no prior chemotherapy for metastatic disease. Similarly the ALK inhibitor trials IPASS (Gefinitib), LUXLung 3 and 6 (Afatinib), PROFILE 1001 (Crizotinib), NP28761 and NP28763 (Alectinib), SATURN and TITAN (erlotinib) had Asians and Whites as the majority of their patients with no transparent data on the percentage of Blacks included in these trials. Other ALK inhibitor trials like ALEX (Alectinib) and ASCEND (Ceritinib) included about 1.3\% of Blacks each and the LUX-Lung 7 trial (Afatinib) included about only $0.3 \%$ Blacks. The lung cancer trials involving the anti-EGFR agent Osimertinib (AURA, AURA2, AURA3 and FLAURA global cohort) had about 0.7-1.4\% Black inclusivity. Compared to above trials and like trials involving Bevacizumab in colorectal cancer, Bevacizumab studies in lung cancer had better representation of Blacks at about $5 \%$ (Table 1). Overall inclusion rates of Blacks in lung cancer trials were poor at around $1 \%$ (Figure 3).

These low inclusion rates are regardless of the following facts. The incidence and mortality rates for lung cancer is more in Black males and White females compared to White males and Black females respectively[98]. Studies have shown that Blacks are susceptible to lung cancer from lighter smoking, and later onset of smoking compared to Whites[118, 119]. Also, racial disparities in lung cancer incidence persists even in never smokers[120]. Total nicotine equivalent which is used in studies as a more complete measure of nicotine uptake has been found to be more in Blacks compared to Whites even after adjusting for the cigarettes per day and CYP2A6 activity, the enzyme that metabolizes nicotine[121, 122]. Genetically Blacks were less likely than Whites to carry driver mutations in genes like EGFR, KRAS, NRAS, HER2, ALK, BRAF, PIK3CA and MEK1 which in turn influences decision making in lung cancer treatment using targeted therapies[123-125]. 


\section{G. Melanoma}

The melanoma trials, COMBI-v, COMBI-d and the BREAK trials that studied the BRAF targeted therapy Dabrafenib and the BRIM trial that studied Vemurafenib (another BRAF targeted therapy) in BRAF mutation positive advanced melanoma had very poor Black inclusivity ranging from $0.2 \%-0 \%$ (Table 1 ). Interestingly this translates to numbers close to zero on an average in melanoma trials. This can at least be partially explained by the lower incidence rates of melanoma in Blacks compared to Whites (33.0 per 100,000 and 20.2 per 100,000 in White men and women respectively vs 1.2 per 100,000 and 1.0 per 100,000 among AA men and women respectively)[126, 127]. Despite lower incidences, melanoma survival rates lag for the Black population and, the histologic types of melanoma associated with poorer prognosis are more common in this population. For example, acral lentiginous melanoma (ALM) is associated with poor survival rates, and a greater proportion of melanomas diagnosed among Blacks are ALM than are melanomas diagnosed among Whites[128].

\section{H. Multiple Myeloma And Leukemias}

\section{Targeted therapy trials- Hematologic malignancies}

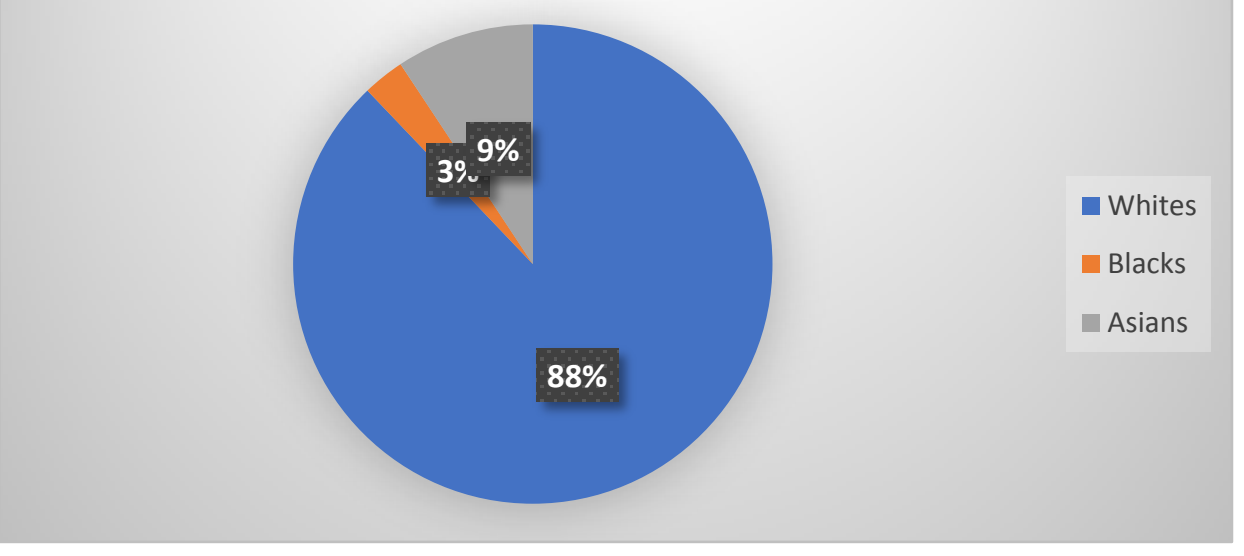

Figure 4. Black inclusion in hematologic cancer trials

The percentage of Blacks in trials involving multiple myeloma $(\mathrm{MM})$ and other hematologic malignancies included in our review is about 2\% (Figure 4). The FDA approval trials for Daratumumab in patients with relapsed or refractory MM, POLLUX trial (Daratumumab with Lenalidomide and Dexamethasone) and CASTOR trial (Daratumumab with Bortezomib and Dexamethasone) had about $2.8 \%$ and 3.6\% Blacks in the trial respectively. Similarly, the ALCYONE trial which fetched FDA approval for Daratumumab combination with Bortezomib, Melphalan, and Prednisone in newly diagnosed MM patients was inclusive of only about $0.8 \%$ Blacks (Table 1). The MURANO trial for Venetoclax with rituximab in elapsed or refractory CML, the IRIS trial for Imatinib and the DASISION trial for Dasatinib in newly diagnosed chronic phase-CML patients included about $0.5 \%, 5 \%$ and $0.5 \%$ Blacks respectively. All three trials lead to FDA approvals of these drugs despite low Black representation. The AML trials, AG120-C-001 (Ivosidenib; IDH1 inhibitor), AG221-C-001 (Enasidenib; IDH2inhibitor) and the ADMIRAL trial (Gilteritinib; FLT3 inhibitor) each had >5\% Blacks represention (Table 1).

These low inclusion numbers are a source of concern as Black Americans are twice at risk of MM and are diagnosed at younger ages compared with Whites[129, 130]. Blacks with family history of MM were more at odds of developing the disease compared to Whites (OR: $20.9,95 \% \mathrm{Cl}: 2.59$ to 168 vs OR: $2.04,95 \% \mathrm{Cl}: 0.83$ to 5.04 ) in one study[131]. A study of $718 \mathrm{MM}$ patients from Multiple Myeloma Research Foundation (CoMMpass study) genetic and clinical data showed higher frequency of certain 
mutations among Black patients. Namely, BCL7A, BRWD3, and AUTS2 gene mutations that are involved in translocations causing B cell malignancies were more frequent among the Blacks representing disparities in biology depending on race[132].

\section{DISCUSSION}

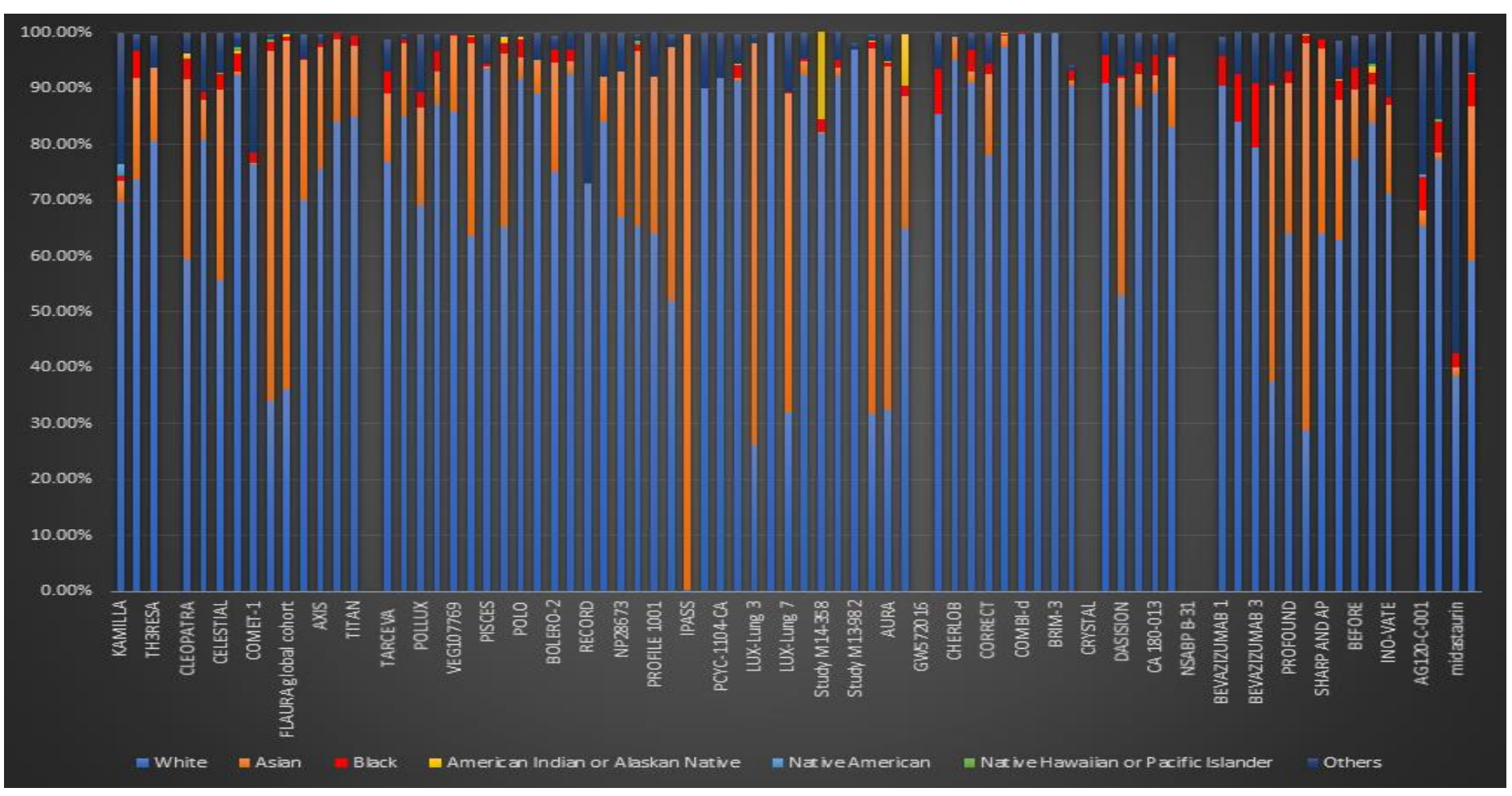

Figure 5. Racial disparities in trial participating

Our results show that most targeted therapy trials including ones that led to FDA approvals had poor representation of Black population (Figure 5). Most trials included in our review were multinational with very few or no Blacks in some participating countries. Given the percentage of Whites collectively included in these multinational trials (about $60-70 \%$ on an average) and with whites constituting about $70 \%$ of the US population[1], it may be reasonable to extrapolate these results to the White population living in the USA. But, Black inclusion rates on an average was only about 1-3\% in the trials included in our review (Figure 2-4). Also, The LUX-Lung 6 (Afatinib) in stage IIIB or IV EGFR mutation-positive lung adenocarcinoma patients had 100\% Asians and no other racial groups including blacks, because of the study location (China, Korea and Thailand). Similarly, BREAK-3 (Dabrafenib) and BRIM-3 (Vemurafenib) trials in malignant melanoma had about $100 \%$ Whites, and no other racial groups. Also, there was a paucity of data on racial demographics in may trials like NSABP B-31 and NCCTG N9831 (Trastuzumab), EORTC 7511-10114 (Trastuzumab and Pertuzumab), EURTAC (Erlotinib), CRYSTAL (Cetuximab) and ALFA-0701 (Gemtuzumab Ozogamicin). The above findings raise concerns on the validity of these results when used to treat the Black population living in the USA.

We are aware that several factors influence cancer treatment including clinical trial participation. A study of psychosocial aspects of BRCA screening among African American (AA) women showed that AA women may underuse available services. Reasons included lack of knowledge on cancer incidence and the role of genetics, concerns about confidentiality and fears of being "used" in research [133]. This along with lack of commercial development in minority low-income neighborhoods results in geographic clustering of health care delivery systems in high income neighborhoods, which in turn makes minority communities less likely to 


\section{THE JOURNAL OF HEALTHCARE ETHICS \& ADMINISTRATION}

Vol. 7 | No. 3 (Summer 2021)

receive newer therapies including therapies in clinical trials [134-136]. In addition, the number of available physicians and other providers may be affected by lower quality of community amenities in the low-income minority communities[137]. Also, race in the U.S. correlates with socioeconomic status (SES) and SES in turn correlates with adequate insurance coverage[138, 139]. Lack of a good insurance coverage might result in denial to cover expenses associated with a clinical trial although clinical trial insurance by the trial investigator or sponsor might cover these costs. This might be a significant barrier to clinical trial enrollment. A recent study demonstrates physician and researcher prejudices that racial minorities like AA's patients are less promising trial candidates, which may result in withholding of trial opportunities [140].

Even if all the above factors are accounted for, differences in genetic alterations, tumor microenvironment and organellar disparities combined with genetic polymorphisms affecting drug sensitivities would add to racial disparities in cancer outcomes. Mutations in $\mathrm{p} 53$ tumor suppressor genes have been associated with poor prognosis in many cancers. Studies have demonstrated higher p53 mutations than previously known in AA breast cancer patients compared to European American (EA) breast cancer patients (odds ratio, 4.00; $95 \%$ confidence interval, $1.77-9.01$ in one study and $19.4 \%$ vs $13.1 \% ; \mathrm{P}<0.05$ in another study) and the difference remained statistically different even after adjusting for age [141, 142]. In addition, studies using breast cancer tissues from AAs and EAs or Caucasians have demonstrated differences in tumor microenvironment[143]. These differences may in turn contribute to differences in tumor progression, aggressiveness, metastasis and treatment outcomes[144].

Also, single nucleotide polymorphisms (SNPs) result in differential distribution of allelic variants across races (Africans vs Caucasians). Depending on the allelic variant for the enzyme, patients may have normal, increased, decreased or absent CYP enzyme function which in turn influences treatment responses[145]. For example, CYP3A enzyme family is responsible for the metabolism of the vinca alkaloids used in the treatment of ALL. Greater than $70 \%$ of AAs carry at least one CYP3A5*1 allele (with most enzyme activity) and thereby express active CYP3A5 enzyme, whereas Caucasians express other alleles (CYP3A5*3, CYP3A5*6, and CYP3A57) with almost no enzyme activity. This translated to increased vincristine neurotoxicity risk in Caucasian children with ALL compared to AA children in one study[146].

Thus, given the differences in biology it is reasonable to doubt the generalizability of the efficacy and safety data from these trials with the very small numbers of Black patients enrolled in these clinical trials. The confidence for generalizability becomes even more limited by the fact that the Black patients enrolled in these trials may not be representative of the broader Black population with multiple comorbidities, as such patients would be excluded from most trials.

\section{THE FUTURE RESET: CLOSING RACIAL DISPARITIES IN CLINICAL TRIALS}

We think that knowledge gaps such as those described above can only be fixed through better trial inclusion rates. A few potential ways to reset the future would be, 1 ) Increasing diversity among cancer care providers, as this would enable better navigation through cultural, societal, and historical factors that influence trial recruitment. 2) Making the healthcare workforce aware that subconscious bias and prejudices not only do exist but also interfere with their ability to serve socially dissimilar patients. 3) Allocation of research resources and incentives from trial sponsors to recruit racial minorities like AAs. 4) Identifying and engaging community stakeholders. 5) Improving communication skills among care providers to enable meaningful conversations with the patient and becoming their trusted partners. 6) Recruiting more Black patients from countries with a considerable Black population to compensate for countries with fewer or no Blacks. 7) Making sure to maintain distributive justice during healthcare policy making. Our review being a retrospective study has the inherent risk of selection bias. The aim of this review was to provide an overview of data on Black inclusivity in targeted therapy clinical trials and to underscore the prevalence of racial disparities among such trials. This review may not be comprehensive of all forms of targeted therapies like cancer vaccines, gene therapy etc. In addition, though other racial groups like Hispanics and Native Americans continue to be underrepresented, discussing all such disparities would be beyond the scope of this review. 


\section{THE JOURNAL OF HEALTHCARE ETHICS \& ADMINISTRATION}

Vol. 7 | No. 3 (Summer 2021)

\section{CONCLUSION}

With tumor related differences, biologic differences, differences in social, economic and lifestyle factors as well as with targeted therapies becoming important milestone in the future, Blacks need better representation in clinical trials moving forward.

\section{REFERENCES}

1. Bureau., U.S.C., https://www.census.gov/quickfacts/fact/table/US/PST045219. 2019.

2. DeSantis, C.E., et al., Cancer statistics for African Americans, 2019. CA: A Cancer Journal for Clinicians, 2019. 69(3): p. 211-233.

3. Dignam, J.J., Differences in breast cancer prognosis among African-American and Caucasian women. CA Cancer J Clin, 2000. 50(1): p. 50-64.

4. Lee, Y.T., Y.J. Tan, and C.E. Oon, Molecular targeted therapy: Treating cancer with specificity. Eur J Pharmacol, 2018. 834: p. 188-196.

5. Suda, K. and T. Mitsudomi, Successes and limitations of targeted cancer therapy in lung cancer. Prog Tumor Res, 2014. 41: p. 62-77.

6. Piccart-Gebhart, M.J., et al., Trastuzumab after adjuvant chemotherapy in HER2-positive breast cancer. N Engl J Med, 2005. 353(16): p. 1659-72.

7. Perez, E.A., et al., Trastuzumab plus adjuvant chemotherapy for human epidermal growth factor receptor 2positive breast cancer: planned joint analysis of overall survival from NSABP B-31 and NCCTG N9831. J Clin Oncol, 2014. 32(33): p. 3744-52.

8. Montemurro, F., et al., Safety of trastuzumab emtansine (T-DM1)\&\#xa0;in patients with HER2-positive advanced breast cancer: Primary results from the KAMILLA study cohort 1. European Journal of Cancer, 2019. 109: p. 92-102.

9. Verma, S., et al., Trastuzumab emtansine for HER2-positive advanced breast cancer. The New England journal of medicine, 2012. 367(19): p. 1783-1791.

10. Krop, I.E., et al., Trastuzumab emtansine versus treatment of physician's choice in patients with previously treated HER2-positive metastatic breast cancer (TH3RESA): final overall survival results from a randomised open-label phase 3 trial. The Lancet Oncology, 2017. 18(6): p. 743-754.

11. Baselga, J., et al., Lapatinib with trastuzumab for HER2-positive early breast cancer (NeoALTTO): a randomised, open-label, multicentre, phase 3 trial. Lancet (London, England), 2012. 379(9816): p. 633-640.

12. Robidoux, A., et al., Lapatinib as a component of neoadjuvant therapy for HER2-positive operable breast cancer (NSABP protocol B-41): an open-label, randomised phase 3 trial. The Lancet Oncology, 2013. 14(12): p. 1183-1192.

13. Geyer, C.E., et al., Lapatinib plus Capecitabine for HER2-Positive Advanced Breast Cancer. New England Journal of Medicine, 2006. 355(26): p. 2733-2743.

14. Guarneri, V., et al., Preoperative chemotherapy plus trastuzumab, lapatinib, or both in human epidermal growth factor receptor 2-positive operable breast cancer: results of the randomized phase II CHER-LOB study. J Clin Oncol, 2012. 30(16): p. 1989-95.

15. Wildiers, H., et al., Pertuzumab and trastuzumab with or without metronomic chemotherapy for older patients with HER2-positive metastatic breast cancer (EORTC 75111-10114): an open-label, randomised, phase 2 trial from the Elderly Task Force/Breast Cancer Group. The Lancet Oncology, 2018. 19(3): p. 323-336.

16. Swain, S.M., et al., Pertuzumab, trastuzumab, and docetaxel for HER2-positive metastatic breast cancer (CLEOPATRA): end-of-study results from a double-blind, randomised, placebo-controlled, phase 3 study. Lancet Oncol, 2020. 21(4): p. 519-530.

17. Baselga, J., et al., Everolimus in postmenopausal hormone-receptor-positive advanced breast cancer. The New England journal of medicine, 2012. 366(6): p. 520-529.

18. Robson, M., et al., Olaparib for Metastatic Breast Cancer in Patients with a Germline BRCA Mutation. New England Journal of Medicine, 2017. 377(6): p. 523-533.

19. Cappuzzo, F., et al., Erlotinib as maintenance treatment in advanced non-small-cell lung cancer: a multicentre, randomised, placebo-controlled phase 3 study. The Lancet Oncology, 2010. 11(6): p. 521-529. 


\section{THE JOURNAL OF HEALTHCARE ETHICS \& ADMINISTRATION}

Vol. 7 | No. 3 (Summer 2021)

20. Ciuleanu, T., et al., Efficacy and safety of erlotinib versus chemotherapy in second-line treatment of patients with advanced, non-small-cell lung cancer with poor prognosis (TITAN): a randomised multicentre, open-label, phase 3 study. Lancet Oncol, 2012. 13(3): p. 300-8.

21. Rosell, R., et al., Erlotinib versus standard chemotherapy as first-line treatment for European patients with advanced EGFR mutation-positive non-small-cell lung cancer (EURTAC): a multicentre, open-label, randomised phase 3 trial. The Lancet Oncology, 2012. 13(3): p. 239-246.

22. Shepherd, F.A., et al., Erlotinib in Previously Treated Non-Small-Cell Lung Cancer. New England Journal of Medicine, 2005. 353(2): p. 123-132.

23. Shaw, A.T., et al., Alectinib in ALK-positive, crizotinib-resistant, non-small-cell lung cancer: a single-group, multicentre, phase 2 trial. The Lancet. Oncology, 2016. 17(2): p. 234-242.

24. Ou, S.H., et al., Alectinib in Crizotinib-Refractory ALK-Rearranged Non-Small-Cell Lung Cancer: A Phase II Global Study. J Clin Oncol, 2016. 34(7): p. 661-8.

25. Mok, T., et al., Updated overall survival and final progression-free survival data for patients with treatment-naive advanced ALK-positive non-small-cell lung cancer in the ALEX study. Ann Oncol, 2020. 31(8): p. 1056-1064.

26. Kim, D.W., et al., Activity and safety of ceritinib in patients with ALK-rearranged non-small-cell lung cancer (ASCEND-1): updated results from the multicentre, open-label, phase 1 trial. Lancet Oncol, 2016. 17(4): p. 452-463.

27. Camidge, D.R., et al., Activity and safety of crizotinib in patients with ALK-positive non-small-cell lung cancer: updated results from a phase 1 study. The Lancet. Oncology, 2012. 13(10): p. 1011-1019.

28. Shaw, A.T., et al., Crizotinib versus Chemotherapy in Advanced ALK-Positive Lung Cancer. New England Journal of Medicine, 2013. 368(25): p. 2385-2394.

29. Yang, J.C.-H., et al., Afatinib versus cisplatin-based chemotherapy for $\langle e m>E G F R</ e m>$ mutation-positive lung adenocarcinoma (LUX-Lung 3 and LUX-Lung 6): analysis of overall survival data from two randomised, phase 3 trials. The Lancet Oncology, 2015. 16(2): p. 141-151.

30. Sequist, L.V., et al., Phase III study of afatinib or cisplatin plus pemetrexed in patients with metastatic lung adenocarcinoma with EGFR mutations. J Clin Oncol, 2013. 31(27): p. 3327-34.

31. Wu, Y.L., et al., Afatinib versus cisplatin plus gemcitabine for first-line treatment of Asian patients with advanced non-small-cell lung cancer harbouring EGFR mutations (LUX-Lung 6): an open-label, randomised phase 3 trial. Lancet Oncol, 2014. 15(2): p. 213-22.

32. Park, K., et al., Afatinib versus gefitinib as first-line treatment of patients with $\langle e m>E G F R</ e m>$ mutation-positive non-small-cell lung cancer (LUX-Lung 7): a phase 2B, open-label, randomised controlled trial. The Lancet Oncology, 2016. 17(5): p. 577-589.

33. Mok, T.S., et al., Gefitinib or Carboplatin-Paclitaxel in Pulmonary Adenocarcinoma. New England Journal of Medicine, 2009. 361(10): p. 947-957.

34. Jänne, P.A., et al., AZD9291 in EGFR inhibitor-resistant non-small-cell lung cancer. N Engl J Med, 2015. 372(18): p. 1689-99.

35. Goss, G., et al., Osimertinib for pretreated <em>EGFR</em> Thr790Met-positive advanced non-small-cell lung cancer (AURA2): a multicentre, open-label, single-arm, phase 2 study. The Lancet Oncology, 2016. 17(12): p. 16431652.

36. Mok, T.S., et al., Osimertinib or Platinum-Pemetrexed in EGFR T790M-Positive Lung Cancer. The New England journal of medicine, 2017. 376(7): p. 629-640.

37. Soria, J.-C., et al., Osimertinib in Untreated EGFR-Mutated Advanced Non-Small-Cell Lung Cancer. New England Journal of Medicine, 2017. 378(2): p. 113-125.

38. Sandler, A., et al., Paclitaxel-Carboplatin Alone or with Bevacizumab for Non-Small-Cell Lung Cancer. New England Journal of Medicine, 2006. 355(24): p. 2542-2550.

39. Bang, Y.-J., et al., Trastuzumab in combination with chemotherapy versus chemotherapy alone for treatment of HER2-positive advanced gastric or gastro-oesophageal junction cancer (ToGA): a phase 3, open-label, randomised controlled trial. The Lancet, 2010. 376(9742): p. 687-697.

40. Abou-Alfa, G.K., et al., Cabozantinib in Patients with Advanced and Progressing Hepatocellular Carcinoma. New England Journal of Medicine, 2018. 379(1): p. 54-63.

41. Kudo, M., et al., Lenvatinib versus sorafenib in first-line treatment of patients with unresectable hepatocellular carcinoma: a randomised phase 3 non-inferiority trial. The Lancet, 2018. 391(10126): p. 1163-1173. 


\section{THE JOURNAL OF HEALTHCARE ETHICS \& ADMINISTRATION}

Vol. 7 | No. 3 (Summer 2021)

42. Golan, T., et al., Maintenance Olaparib for Germline BRCA-Mutated Metastatic Pancreatic Cancer. The New England journal of medicine, 2019. 381(4): p. 317-327.

43. Grothey, A., et al., Regorafenib monotherapy for previously treated metastatic colorectal cancer (CORRECT): an international, multicentre, randomised, placebo-controlled, phase 3 trial. Lancet, 2013. 381(9863): p. 303-12.

44. Douillard, J.-Y., et al., Randomized, Phase III Trial of Panitumumab With Infusional Fluorouracil, Leucovorin, and Oxaliplatin (FOLFOX4) Versus FOLFOX4 Alone As First-Line Treatment in Patients With Previously Untreated Metastatic Colorectal Cancer: The PRIME Study. Journal of Clinical Oncology, 2010. 28(31): p. 4697-4705.

45. Van Cutsem, E., et al., Cetuximab and Chemotherapy as Initial Treatment for Metastatic Colorectal Cancer. New England Journal of Medicine, 2009. 360(14): p. 1408-1417.

46. Hurwitz, H., et al., Bevacizumab plus Irinotecan, Fluorouracil, and Leucovorin for Metastatic Colorectal Cancer. New England Journal of Medicine, 2004. 350(23): p. 2335-2342.

47. Kabbinavar, F.F., et al., Addition of bevacizumab to bolus fluorouracil and leucovorin in first-line metastatic colorectal cancer: results of a randomized phase II trial. J Clin Oncol, 2005. 23(16): p. 3697-705.

48. Choueiri, T.K., et al., Cabozantinib versus sunitinib as initial therapy for metastatic renal cell carcinoma of intermediate or poor risk (Alliance A031203 CABOSUN randomised trial): Progression-free survival by independent review and overall survival update. European journal of cancer (Oxford, England : 1990), 2018. 94: p. $115-125$.

49. Sternberg, C.N., et al., Pazopanib in locally advanced or metastatic renal cell carcinoma: results of a randomized phase III trial. J Clin Oncol, 2010. 28(6): p. 1061-8.

50. Motzer, R.J., et al., Pazopanib versus sunitinib in metastatic renal-cell carcinoma. N Engl J Med, 2013. 369(8): p. 722-31.

51. Guo, J., et al., Safety of pazopanib and sunitinib in treatment-naive patients with metastatic renal cell carcinoma: Asian versus non-Asian subgroup analysis of the COMPARZ trial. Journal of hematology \& oncology, 2018. 11(1): p. 69-69.

52. Escudier, B., et al., Randomized, controlled, double-blind, cross-over trial assessing treatment preference for pazopanib versus sunitinib in patients with metastatic renal cell carcinoma: PISCES Study. J Clin Oncol, 2014. 32(14): p. 1412-8.

53. Motzer, R.J., et al., Efficacy of everolimus in advanced renal cell carcinoma: a double-blind, randomised, placebocontrolled phase III trial. Lancet, 2008. 372(9637): p. 449-56.

54. Motzer, R.J., et al., Sunitinib versus interferon alfa in metastatic renal-cell carcinoma. N Engl J Med, 2007. 356(2): p. 115-24.

55. Escudier, B., et al., Sorafenib in advanced clear-cell renal-cell carcinoma. N Engl J Med, 2007. 356(2): p. 125-34.

56. Hudes, G., et al., Temsirolimus, Interferon Alfa, or Both for Advanced Renal-Cell Carcinoma. New England Journal of Medicine, 2007. 356(22): p. 2271-2281.

57. Hutson, T.E., et al., Axitinib versus sorafenib as first-line therapy in patients with metastatic renal-cell carcinoma: a randomised open-label phase 3 trial. Lancet Oncol, 2013. 14(13): p. 1287-94.

58. Motzer, R.J., et al., Axitinib versus sorafenib as second-line treatment for advanced renal cell carcinoma: overall survival analysis and updated results from a randomised phase 3 trial. The Lancet Oncology, 2013. 14(6): p. 552562.

59. Choueiri, T.K., et al., Cabozantinib versus everolimus in advanced renal cell carcinoma (METEOR): final results from a randomised, open-label, phase 3 trial. Lancet Oncol, 2016. 17(7): p. 917-927.

60. Smith, M., et al., Phase III Study of Cabozantinib in Previously Treated Metastatic Castration-Resistant Prostate Cancer: COMET-1. J Clin Oncol, 2016. 34(25): p. 3005-13.

61. de Bono, J., et al., Olaparib for Metastatic Castration-Resistant Prostate Cancer. New England Journal of Medicine, 2020. 382(22): p. 2091-2102.

62. Kantarjian, H., et al., Blinatumomab versus Chemotherapy for Advanced Acute Lymphoblastic Leukemia. The New England journal of medicine, 2017. 376(9): p. 836-847.

63. Kantarjian, H.M., et al., Inotuzumab Ozogamicin versus Standard Therapy for Acute Lymphoblastic Leukemia. New England Journal of Medicine, 2016. 375(8): p. 740-753.

64. Wang, M.L., et al., Targeting BTK with ibrutinib in relapsed or refractory mantle-cell lymphoma. The New England journal of medicine, 2013. 369(6): p. 507-516.

65. Byrd, J.C., et al., Ibrutinib versus ofatumumab in previously treated chronic lymphoid leukemia. N Engl J Med, 2014. 371(3): p. 213-23. 


\section{THE JOURNAL OF HEALTHCARE ETHICS \& ADMINISTRATION}

Vol. 7 | No. 3 (Summer 2021)

66. Chanan-Khan, A., et al., Ibrutinib combined with bendamustine and rituximab compared with placebo, bendamustine, and rituximab for previously treated chronic lymphocytic leukaemia or small lymphocytic lymphoma (HELIOS): a randomised, double-blind, phase 3 study. Lancet Oncol, 2016. 17(2): p. 200-211.

67. Seymour, J.F., et al., Venetoclax-Rituximab in Relapsed or Refractory Chronic Lymphocytic Leukemia. New England Journal of Medicine, 2018. 378(12): p. 1107-1120.

68. Stilgenbauer, S., et al., Venetoclax in relapsed or refractory chronic lymphocytic leukaemia with 17p deletion: a multicentre, open-label, phase 2 study. Lancet Oncol, 2016. 17(6): p. 768-778.

69. DiNardo, C.D., et al., Venetoclax combined with decitabine or azacitidine in treatment-naive, elderly patients with acute myeloid leukemia. Blood, 2019. 133(1): p. 7-17.

70. Wei, A.H., et al., Venetoclax Combined With Low-Dose Cytarabine for Previously Untreated Patients With Acute Myeloid Leukemia: Results From a Phase Ib/II Study. Journal of clinical oncology : official journal of the American Society of Clinical Oncology, 2019. 37(15): p. 1277-1284.

71. Lambert, J., et al., Gemtuzumab ozogamicin for de novo acute myeloid leukemia: final efficacy and safety updates from the open-label, phase III ALFA-0701 trial. Haematologica, 2019. 104(1): p. 113-119.

72. Roboz, G.J., et al., Ivosidenib induces deep durable remissions in patients with newly diagnosed IDH1-mutant acute myeloid leukemia. Blood, 2020. 135(7): p. 463-471.

73. DiNardo, C.D., et al., Durable Remissions with Ivosidenib in IDH1-Mutated Relapsed or Refractory AML. New England Journal of Medicine, 2018. 378(25): p. 2386-2398.

74. Stein, E.M., et al., Enasidenib in patients with mutant IDH2 myelodysplastic syndromes: a phase 1 subgroup analysis of the multicentre, AG221-C-001 trial. Lancet Haematol, 2020. 7(4): p. e309-e319.

75. Stein, E.M., Enasidenib, a targeted inhibitor of mutant IDH2 proteins for treatment of relapsed or refractory acute myeloid leukemia. Future Oncol, 2018. 14(1): p. 23-40.

76. Stone, R.M., et al., Midostaurin plus Chemotherapy for Acute Myeloid Leukemia with a FLT3 Mutation. The New England journal of medicine, 2017. 377(5): p. 454-464.

77. Perl, A.E., et al., Gilteritinib or Chemotherapy for Relapsed or Refractory FLT3-Mutated AML. New England Journal of Medicine, 2019. 381(18): p. 1728-1740.

78. Druker, B.J., et al., Five-Year Follow-up of Patients Receiving Imatinib for Chronic Myeloid Leukemia. New England Journal of Medicine, 2006. 355(23): p. 2408-2417.

79. Cortes, J.E., et al., Final 5-Year Study Results of DASISION: The Dasatinib Versus Imatinib Study in Treatment-Naïve Chronic Myeloid Leukemia Patients Trial. Journal of clinical oncology : official journal of the American Society of Clinical Oncology, 2016. 34(20): p. 2333-2340.

80. Kantarjian, H., et al., Dasatinib or high-dose imatinib for chronic-phase chronic myeloid leukemia resistant to imatinib at a dose of 400 to 600 milligrams daily: two-year follow-up of a randomized phase 2 study (START-R). Cancer, 2009. 115(18): p. 4136-47.

81. Mauro, M.J., et al., Dasatinib 2-year efficacy in patients with chronic-phase chronic myelogenous leukemia (CML$C P$ ) with resistance or intolerance to imatinib (START-C). Journal of Clinical Oncology, 2008. 26(15_suppl): p. 70097009.

82. Saglio, G., et al., Nilotinib versus Imatinib for Newly Diagnosed Chronic Myeloid Leukemia. New England Journal of Medicine, 2010. 362(24): p. 2251-2259.

83. Cortes, J.E., et al., Bosutinib Versus Imatinib for Newly Diagnosed Chronic Myeloid Leukemia: Results From the Randomized BFORE Trial. Journal of clinical oncology : official journal of the American Society of Clinical Oncology, 2018. 36(3): p. 231-237.

84. Mateos, M.V., et al., Daratumumab plus Bortezomib, Melphalan, and Prednisone for Untreated Myeloma. N Engl J Med, 2018. 378(6): p. 518-528.

85. Dimopoulos, M.A., et al., Daratumumab, Lenalidomide, and Dexamethasone for Multiple Myeloma. New England Journal of Medicine, 2016. 375(14): p. 1319-1331.

86. Palumbo, A., et al., Daratumumab, Bortezomib, and Dexamethasone for Multiple Myeloma. New England Journal of Medicine, 2016. 375(8): p. 754-766.

87. Robert, C., et al., Improved overall survival in melanoma with combined dabrafenib and trametinib. N Engl J Med, 2015. 372(1): p. 30-9.

88. Long, G.V., et al., Combined BRAF and MEK Inhibition versus BRAF Inhibition Alone in Melanoma. New England Journal of Medicine, 2014. 371(20): p. 1877-1888. 


\section{THE JOURNAL OF HEALTHCARE ETHICS \& ADMINISTRATION}

Vol. 7 | No. 3 (Summer 2021)

89. Hauschild, A., et al., Dabrafenib in BRAF-mutated metastatic melanoma: a multicentre, open-label, phase 3 randomised controlled trial. Lancet, 2012. 380(9839): p. 358-65.

90. Chapman, P.B., et al., Vemurafenib in patients with BRAFV600 mutation-positive metastatic melanoma: final overall survival results of the randomized BRIM-3 study. Ann Oncol, 2017. 28(10): p. 2581-2587.

91. Breast Cancer Facts \& Figures 2019-2020. American cancer society. Atlanta: American Cancer Society, Inc. 2019.

92. Smigal, C., et al., Trends in Breast Cancer by Race and Ethnicity: Update 2006. CA: A Cancer Journal for Clinicians, 2006. 56(3): p. 168-183.

93. Royak-Schaler, R., et al., Breast cancer in African-American families. Risk perception, cancer worry, and screening practices of first-degree relatives. Ann N Y Acad Sci, 1995. 768: p. 281-5.

94. Lannin, D.R., et al., Influence of Socioeconomic and Cultural Factors on Racial Differences in Late-Stage Presentation of Breast Cancer. JAMA, 1998. 279(22): p. 1801-1807.

95. Dawson, D.A. and G.B. Thompson, Breast cancer risk factors and screening: United States, 1987. Vital Health Stat 10, 1990(172): p. iii-iv, 1-60.

96. Yao, S. and C.B. Ambrosone, Associations between vitamin D deficiency and risk of aggressive breast cancer in African-American women. J Steroid Biochem Mol Biol, 2013. 136: p. 337-41.

97. Tammemagi, C.M., et al., Comorbidity and survival disparities among black and white patients with breast cancer. Jama, 2005. 294(14): p. 1765-72.

98. Siegel, R.L., K.D. Miller, and A. Jemal, Cancer statistics, 2020. CA: A Cancer Journal for Clinicians, 2020. 70(1): p. 730.

99. Jackson, C.S., et al., Health disparities in colorectal cancer among racial and ethnic minorities in the United States. Journal of gastrointestinal oncology, 2016. 7(Suppl 1): p. S32-S43.

100. Theuer, C.P., et al., Racial and ethnic colorectal cancer patterns affect the cost-effectiveness of colorectal cancer screening in the United States. Gastroenterology, 2001. 120(4): p. 848-56.

101. Yoon, H.H., et al., Racial Differences in BRAF/KRAS Mutation Rates and Survival in Stage III Colon Cancer Patients. JNCl: Journal of the National Cancer Institute, 2015. 107(10).

102. Carethers, J.M., et al., Influence of race on microsatellite instability and CD8+ T cell infiltration in colon cancer. PLoS One, 2014. 9(6): p. e100461.

103. Bruix, J., et al., Prognostic factors and predictors of sorafenib benefit in patients with hepatocellular carcinoma: Analysis of two phase III studies. Journal of Hepatology, 2017. 67(5): p. 999-1008.

104. $\mathrm{Xu}, \mathrm{L}$., et al., Racial disparities in treatment and survival of patients with hepatocellular carcinoma in the United States. Hepatobiliary surgery and nutrition, 2016. 5(1): p. 43-52.

105. Sloane, D., H. Chen, and C. Howell, Racial disparity in primary hepatocellular carcinoma: tumor stage at presentation, surgical treatment and survival. J Natl Med Assoc, 2006. 98(12): p. 1934-9.

106. Rich, N.E., et al., Racial and Ethnic Differences in Presentation and Outcomes of Hepatocellular Carcinoma. Clin Gastroenterol Hepatol, 2019. 17(3): p. 551-559.e1.

107. Muglia, V.F. and A. Prando, Renal cell carcinoma: histological classification and correlation with imaging findings. Radiologia brasileira, 2015. 48(3): p. 166-174.

108. Chow, W.-H., et al., Racial disparity in renal cell carcinoma patient survival according to demographic and clinical characteristics. Cancer, 2013. 119(2): p. 388-394.

109. Krishnan, B., et al., Intrinsic Genomic Differences Between African American and White Patients With Clear Cell Renal Cell Carcinoma. JAMA oncology, 2016. 2(5): p. 664-667.

110. Ravery, V., et al., Prostate cancer characteristics in a multiracial community. Eur Urol, 2008. 53(3): p. 533-8.

111. Sundi, D., et al., African American men with very low-risk prostate cancer exhibit adverse oncologic outcomes after radical prostatectomy: should active surveillance still be an option for them? J Clin Oncol, 2013. 31(24): p. 2991-7.

112. Moul, J.W., et al., Prostate-specific antigen values at the time of prostate cancer diagnosis in African-American men. Jama, 1995. 274(16): p. 1277-81.

113. Faisal, F.A., et al., Racial Variations in Prostate Cancer Molecular Subtypes and Androgen Receptor Signaling Reflect Anatomic Tumor Location. European urology, 2016. 70(1): p. 14-17.

114. Sundi, D., et al., Reclassification rates are higher among African American men than Caucasians on active surveillance. Urology, 2015. 85(1): p. 155-160.

115. Powell, I.J., et al., Genes associated with prostate cancer are differentially expressed in African American and European American men. Cancer Epidemiol Biomarkers Prev, 2013. 22(5): p. 891-7. 
116. Petrovics, G., et al., MP39-18 HIGHER FREQUENCY OF GERMLINE BRCA1 AND BRCA2 MUTATIONS IN AFRICAN AMERICAN PROSTATE CANCER. Journal of Urology, 2016. 195(4S): p. e548-e548.

117. Smith, R.A., et al., Cancer screening in the United States, 2018: A review of current American Cancer Society guidelines and current issues in cancer screening. CA: A Cancer Journal for Clinicians, 2018. 68(4): p. 297-316.

118. Haiman, C.A., et al., Ethnic and racial differences in the smoking-related risk of lung cancer. N Engl J Med, 2006. 354(4): p. 333-42.

119. White, H.R., et al., Stages and sequences of initiation and regular substance use in a longitudinal cohort of black and white male adolescents. J Stud Alcohol Drugs, 2007. 68(2): p. 173-81.

120. Thun, M.J., et al., Lung cancer occurrence in never-smokers: an analysis of 13 cohorts and 22 cancer registry studies. PLoS Med, 2008. 5(9): p. e185.

121. Benowitz, N.L., et al., Racial differences in the relationship between number of cigarettes smoked and nicotine and carcinogen exposure. Nicotine \& tobacco research : official journal of the Society for Research on Nicotine and Tobacco, 2011. 13(9): p. 772-783.

122. Park, S.L., et al., Genetic determinants of CYP2A6 activity across racial/ethnic groups with different risks of lung cancer and effect on their smoking intensity. Carcinogenesis, 2016. 37(3): p. 269-279.

123. Lusk, C.M., et al., Profiling the Mutational Landscape in Known Driver Genes and Novel Genes in African American Non-Small Cell Lung Cancer Patients. Clinical Cancer Research, 2019. 25(14): p. 4300-4308.

124. Bollig-Fischer, A., et al., Racial diversity of actionable mutations in non-small cell lung cancer. J Thorac Oncol, 2015. 10(2): p. 250-5.

125. Araujo, L.H., et al., Somatic Mutation Spectrum of Non-Small-Cell Lung Cancer in African Americans: A Pooled Analysis. J Thorac Oncol, 2015. 10(10): p. 1430-6.

126. Mahendraraj, K., et al., Malignant Melanoma in African-Americans: A Population-Based Clinical Outcomes Study Involving 1106 African-American Patients from the Surveillance, Epidemiology, and End Result (SEER) Database (1988-2011). Medicine, 2017. 96(15): p. e6258-e6258.

127. Hu, S., et al., UV radiation, latitude, and melanoma in US Hispanics and blacks. Arch Dermatol, 2004. 140(7): p. 819-24.

128. Culp MB, L.N., Melanoma Among Non-Hispanic Black Americans. Prev Chronic Dis 2019;16:180640.

129. Benjamin, M., S. Reddy, and O.W. Brawley, Myeloma and race: a review of the literature. Cancer Metastasis Rev, 2003. 22(1): p. 87-93.

130. Waxman, A.J., et al., Racial disparities in incidence and outcome in multiple myeloma: a population-based study. Blood, 2010. 116(25): p. 5501-6.

131. VanValkenburg, M.E., et al., Family history of hematologic malignancies and risk of multiple myeloma: differences by race and clinical features. Cancer Causes Control, 2016. 27(1): p. 81-91.

132. Manojlovic, Z., et al., Comprehensive molecular profiling of 718 Multiple Myelomas reveals significant differences in mutation frequencies between African and European descent cases. PLoS genetics, 2017. 13(11): p. e1007087e1007087.

133. Matthews, A.K., et al., Genetic Testing of African Americans for Susceptibility to Inherited Cancers. Journal of Psychosocial Oncology, 2000. 18(2): p. 1-19.

134. Nguyen, C., et al., Comparison of Healthcare Delivery Systems in Low- and High-Income Communities. 2019.

135. Breslin, T.M., et al., Hospital factors and racial disparities in mortality after surgery for breast and colon cancer. J Clin Oncol, 2009. 27(24): p. 3945-50.

136. Keating, N.L., et al., Racial differences in definitive breast cancer therapy in older women: are they explained by the hospitals where patients undergo surgery? Med Care, 2009. 47(7): p. 765-73.

137. Gaskin, D.J., et al., Residential Segregation and the Availability of Primary Care Physicians. Health Services Research, 2012. 47(6): p. 2353-2376.

138. Fontenot, K., J. Semega, and M. Kollar, Income and poverty in the United States: 2017. Washington, DC: US Census Bureau, 2018: p. P60-263.

139. Berchick, E.R., E. Hood, and J.C. Barnett, Health insurance coverage in the United States: 2017. Current population reports. Washington DC: US Government Printing Office, 2018.

140. Niranjan, S.J., et al., Bias and stereotyping among research and clinical professionals: Perspectives on minority recruitment for oncology clinical trials. Cancer, 2020. 126(9): p. 1958-1968. 


\section{THE JOURNAL OF HEALTHCARE ETHICS \& ADMINISTRATION}

Vol. 7 | No. 3 (Summer 2021)

141. Jones, B.A., et al., African-American/White differences in breast carcinoma: p53 alterations and other tumor characteristics. Cancer, 2004. 101(6): p. 1293-301.

142. Morris, G.J., et al., Differences in breast carcinoma characteristics in newly diagnosed African-American and Caucasian patients: a single-institution compilation compared with the National Cancer Institute's Surveillance, Epidemiology, and End Results database. Cancer, 2007. 110(4): p. 876-84.

143. Deshmukh, S.K., et al., Emerging evidence for the role of differential tumor microenvironment in breast cancer racial disparity: a closer look at the surroundings. Carcinogenesis, 2017. 38(8): p. 757-765.

144. Dumont, N., et al., Breast fibroblasts modulate early dissemination, tumorigenesis, and metastasis through alteration of extracellular matrix characteristics. Neoplasia (New York, N.Y.), 2013. 15(3): p. $249-262$.

145. Rajman, I., et al., African Genetic Diversity: Implications for Cytochrome P450-mediated Drug Metabolism and Drug Development. EBioMedicine, 2017. 17: p. 67-74.

146. Egbelakin, A., et al., Increased risk of vincristine neurotoxicity associated with low CYP3A5 expression genotype in children with acute lymphoblastic leukemia. Pediatric blood \& cancer, 2011. 56(3): p. 361-367. 